\title{
Laparoscopic upper vaginectomy for post-hysterectomy high risk vaginal intraepithelial neoplasia and superficially invasive vaginal carcinoma
}

Youn Jin Choi, Soo Young Hur, Jong Sup Park and Keun Ho Lee*

\begin{abstract}
Background: The aim of this study is to describe the feasibility and efficacy of the laparoscopic upper vaginectomy (LUV) in vaginal intraepithelial neoplasia(VAIN) and superficially invasive vaginal carcinoma.

Methods: We studied patients with vaginal intraepithelial neoplasia (VAIN) 2, VAIN 3, and superficially invasive vaginal carcinoma after hysterectomy who have been under laparoscopic upper vaginectomy between March 2010 and March 2012.

Results: Four patients underwent LUV after hysterectomy for high risk VAIN and early vaginal cancer. The mean age was 50.8 (range 40-56) years; the mean operation time was 162.5 (range 145-205) minutes; and the mean estimated blood loss was 55 (range 20-100) $\mathrm{ml}$. All the patients restituted bladder function after the removal of the foley catheter. Mean hospital stay was 2 days. Two patients had postoperative complications. One patient with warfarin administration had vaginal stump bleeding and another developed vesico-vaginal fistula. Three of the patients had no residual lesion, but 1 patient had VAIN 1 in the resection margin. Colposcopy was followed on all patients and cytology proved no recurrence.
\end{abstract}

Conclusions: LUV after hysterectomy is a feasible procedure and attentively applicable to high risk VAIN or superficially invasive vaginal carcinoma.

Keywords: Vaginal carcinoma, Vaginal intraepithelial neoplasia, Vaginectomy

\section{Background}

Vaginal intraepithelial neoplasia (VAIN) and vaginal carcinoma are rare clinical entities. Human papillomavirus infection, immunosuppression, radiation therapy, and smoking are reported to be the risk factors [1]. Upper vaginectomy is a technique applicable to the patients with cervical cancer after simple hysterectomy, vaginal recurrence of endometrial cancer, vaginal intraepithelial neoplasia, and superficially invasive vaginal carcinoma. The operation method has mostly been attempted via the vagina [2-4]. A few studies have reported using the laparoscopic approach, including robotically assisted laparoscopic vaginectomy $[2,5,6]$.

\footnotetext{
* Correspondence: hohoho@catholic.ac.kr

Department of Obstetrics \& Gynecology, Seoul St. Mary's hospital, College of Medicine, The Catholic university of Korea, 505 Banpo-dong Seocho-gu, Seoul 137-040, South Korea
}

(c) 2013 Choi et al.; licensee BioMed Central Ltd. This is an Open Access article distributed under the terms of the Creative Commons Attribution License (http://creativecommons.org/licenses/by/2.0), which permits unrestricted use, distribution, and reproduction in any medium, provided the original work is properly cited.

\section{Methods}

The charts of the patients with VAIN 2, VAIN 3, and superficial vaginal carcinoma after hysterectomy, who have undergone laparoscopic vaginectomy between March 2010 and March 2012 were reviewed retrospectively. The patient details are described in Table 1.

Colposcopy (Carl Zeiss, Inc., Berlin, Germany) was checked on all the patients to determine the resection area preoperatively. The lesions were confined to the upper one third of the vagina (Figure 1A). Under general anesthesia,
However, to the best of our knowledge, there has been no study reporting laparoscopic vaginectomy in VAIN and tomy. The aim of this study was to describe the feasibility and efficacy of laparoscopic vaginectomy in VAIN. 
Table 1 Characteristics of the patients

\begin{tabular}{|c|c|c|c|c|}
\hline & Patient 1 & Patient 2 & Patient 3 & Patient 4 \\
\hline Age, years & 40 & 56 & 51 & 56 \\
\hline $\begin{array}{l}\text { Body mass index, } \\
\mathrm{kg} / \mathrm{m}^{2}\end{array}$ & 21.78 & 31.35 & 25.31 & 20.13 \\
\hline HPV genotype & 58 & 56 & 18 & Not checked \\
\hline $\begin{array}{l}\text { Previous } \\
\text { hysterectomy } \\
\text { indication }\end{array}$ & $\begin{array}{l}\text { Cervical } \\
\text { carcinoma }\end{array}$ & $\begin{array}{l}\text { Cervical } \\
\text { cancer IB }\end{array}$ & $\begin{array}{l}\text { Myoma } \\
\text { uteri }\end{array}$ & Myoma uteri \\
\hline $\begin{array}{l}\text { Preoperative } \\
\text { diagnosis }\end{array}$ & VAIN 3 & VAIN 2 & VAIN 2 & $\begin{array}{l}\text { Squamous cell } \\
\text { carcinoma }\end{array}$ \\
\hline $\begin{array}{l}\text { Interval between the } \\
\text { operations, years }\end{array}$ & 11 & 20 & 16 & 14 \\
\hline
\end{tabular}

HPV human papilloma virus, VAIN vaginal intraepithelial neoplasia.

the patients were placed in the Trendelenberg position and a Foley catheter was inserted. Iodine was applied on the vagina to confirm the lesion. Then, either a three-ports or single-port laparoscopic technique was performed. For the three-ports technique, one $12-\mathrm{mm}$ trocar in the intraumbilicus and two 5-mm trocars in the lateral abdominal walls were used. For the single port technique, Octoport $^{\mathrm{mix}}$ (Dalim surginet, Seoul, Korea) was applied. The abdomen was explored and adhesiolysis was done to secure an operation field. A rolled gauze grasped by a sponge forcep was inserted in the vagina and held with gentle upward pressure to keep adequate tension between the vagina and attendant connective tissues. After opening of visceral peritoneum over the apex of stump, the vesicovaginal and rectovaginal spaces were dissected through the scar tissue and the bladder pillar was isolated (Figure 1B and C). After the successful separation of the vaginal apex from the bladder serosa, a circumferential vaginal incision was performed and the specimen was removed (Figure 1D). The vaginal cuff was closed with a running suture using an absorbable suture (Figure 1E). The bladder was filled with normal saline to secure the dissected weak point. Supplementary pelvic lymphadenectomy was performed in the patient with vaginal cancer (patient 4). The patients were admitted until the general condition was recovered. Then, they were scheduled to visit the gynecologist's office at 2 weeks after surgery to confirm the final diagnosis and plan further management.

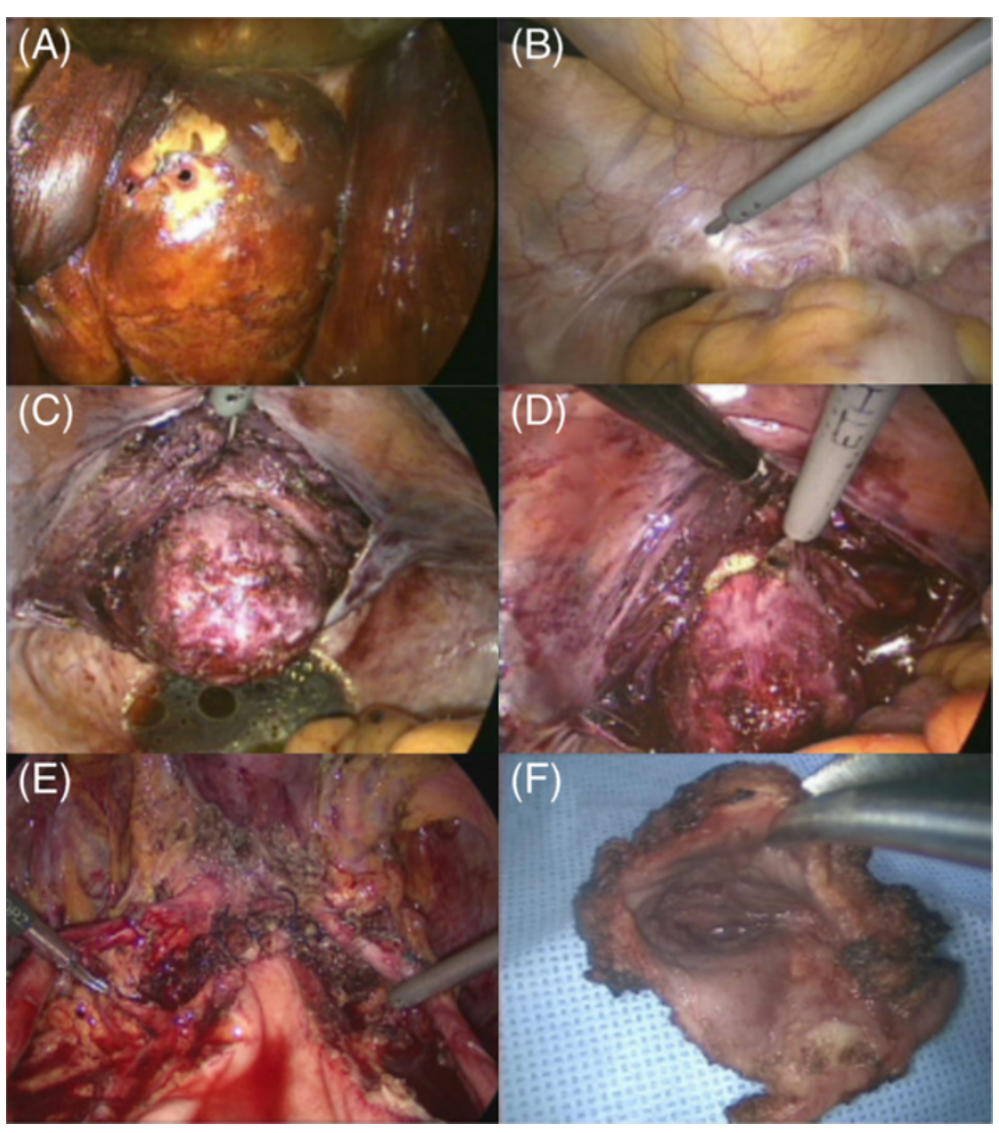

Figure 1 Surgical procedures in laparoscopic upper vaginectomy. (A) The planned cutting margin was identified after iodine application via a speculum examination. (B) Excision of the stump peritoneum. (C) The vaginal stump at the site of dissection of the vesicovaginal and rectovaginal spaces through the scar tissue and the isolation of the bladder pillar. (D) The resection of the upper vagina. (E) The vaginal cutting edge is restored. (F) The dissected upper vaginal specimen. 
Table 2 Operative data of the patients

\begin{tabular}{|c|c|c|c|c|}
\hline & Patient 1 & Patient 2 & Patient 3 & Patient 4 \\
\hline Operation & $\begin{array}{l}\text { Laparoscopic partial } \\
\text { upper vaginectomy }\end{array}$ & $\begin{array}{l}\text { Laparoscopic partial } \\
\text { upper vaginectomy }\end{array}$ & $\begin{array}{l}\text { Laparoscopic partial } \\
\text { upper vaginectomy }\end{array}$ & $\begin{array}{l}\text { Laparoscopic partial upper vaginectomy and } \\
\text { bilateral pelvic lymphadenectomy }\end{array}$ \\
\hline Operation time, minutes & 150 & 150 & 145 & 205 \\
\hline Estimated blood loss, ml & 20 & 50 & 50 & 100 \\
\hline Size of vaginal tissue, $\mathrm{cm}$ & $4.2 \times 4.0$ & $3.7 \times 3.2$ & $3.1 \times 2.9$ & $3.8 \times 2.8$ \\
\hline $\begin{array}{l}\text { Removal of Foley } \\
\text { catheter, postoperative } \\
\text { day }\end{array}$ & 0 & 5 & 1 & 1 \\
\hline Hospital stay, days & 3 & 1 & 2 & 2 \\
\hline Final pathology & $\begin{array}{l}\text { VAIN } 3 \text { (positive resection } \\
\text { margin with VAIN 1) }\end{array}$ & VAIN 1 & Chronic inflammation & Chronic inflammation \\
\hline $\begin{array}{l}\text { Postoperative } \\
\text { complications and } \\
\text { management }\end{array}$ & $\begin{array}{l}\text { Bleeding (warfarin user); } \\
\text { gauze packing }\end{array}$ & None & $\begin{array}{l}\text { Vesicovaginal fistula; } \\
\text { indwelling catheter }\end{array}$ & None \\
\hline
\end{tabular}

\section{Results}

The mean age was 50.8 (range 40 to 56 ) years. Three patients were diagnosed with high-grade VAIN (stage 2 to 3 ) and one with early vaginal cancer. Indications for previous hysterectomy were myoma uteri, carcinoma in situ, and cervical malignancy (two patients, one patient, and one patient, respectively) (Table 1). Single port laparoscopy was performed on one patient and multi-port laparoscopy was performed on the rest. The mean operation time was 162.5 (range 145 to 205) minutes and the mean estimated blood loss was 55 (range 20 to 100) $\mathrm{ml}$. One patient had the Foley catheter removed on the operation day, two on the postoperative day 1 , and one on postoperative day 5 . All the patients restituted bladder function after the removal of the Foley catheter. They were discharged from hospital before postoperative day 3. Patient 1 had a final diagnosis of VAIN 3 and the histology confirmed VAIN 1 in the resection margin. Patient 4 had preoperative diagnosis of squamous cell carcinoma from the vaginal cytology, but the final pathological diagnosis from the vaginal stump was chronic inflammation (Table 2).

Patient 1 had been under administration of warfarin due to mitral valve regurgitation. Warfarin was replaced by heparin for 3 days and the patient stopped the medication 1 day before the operation. On postoperative day 3 , the warfarin was restarted, however, vaginal bleeding developed on postoperative day 12 . The bleeding stopped after gauze packing. Patient 3 developed a vesicovaginal fistula. It was not found during the operation even after filling the bladder with blue-dyed normal saline to check the dissected weak point. Conservative management was followed; the Foley catheter was kept in place for 3 months and then the fistula was spontaneously closed. All patients were followed for 11 to 29 months and colposcopy and cytology proved no recurrence.

\section{Discussion}

Vaginal carcinoma represents $2 \%$ to $3 \%$ of malignancy of the female genital tract and VAIN $<1 \%$ of intraepithelial neoplasia [7-9]. VAIN 1 regresses spontaneously, therefore it does not require treatment [10]. For VAIN 2 and 3, no consensus on the most effective treatment has been established and various treatment modalities have been proposed, including local excision, partial or total vaginectomy, radiotherapy, laser vaporization, and topical 5-fluorouracil administration [11]. Rome et al. grouped 132 VAIN and early invasive vaginal cancer patients according to different treatment modalities and reported the long-term follow up results. The cure rates were $69 \%, 69 \%$, and $45 \%$ when excision, laser ablation and chemical treatment were performed, respectively [3]. Radiation may be an efficacious treatment modality, however, it results in severe adverse effects, including vaginal stenosis, urinary symptoms, and vaginal ulceration [12].

Table 3 Summary of cases of upper vaginectomy in VAIN 2 to 3

\begin{tabular}{|c|c|c|c|c|c|}
\hline Authors & Number of cases & Procedure & Complication rate & $\begin{array}{l}\text { Recurrence } \\
\text { rate }\end{array}$ & $\begin{array}{l}\text { Occult } \\
\text { malignancy }\end{array}$ \\
\hline Indermaur $^{7}$ & 105 & Upper vaginectomy & $10 \%$ & $12 \%$ & $12 \%$ \\
\hline Hoffman $^{4}$ & 32 & Upper vaginectomy & $22 \%$ & $16 \%$ & $28 \%$ \\
\hline Diakomanolis $^{11}$ & 24 & Upper vaginectomy & Not mentioned & $21 \%$ & Not mentioned \\
\hline This series & $\begin{array}{l}4 \text { (including } 1 \text { vaginal } \\
\text { cancer) }\end{array}$ & $\begin{array}{l}\text { Laparoscopic upper } \\
\text { vaginecotmy }\end{array}$ & $\begin{array}{l}50 \% \text { ( } 1 \text { postopertive bleeding, } 1 \\
\text { vesicovaginal fistula) }\end{array}$ & $0 \%$ & $0 \%$ \\
\hline
\end{tabular}


There are various advantages of upper vaginectomy. First, it is a treatment modality that provides complete histopathologic information, therefore an occult malignancy is often discovered. When compared to excision, upper vaginectomy provides whole tissue, not the tissue in pieces and the lesion is removed in full depth. Moreover, vaginal lesions are multifocal and a thorough diagnostic evaluation to rule out invasive cancer is difficult; in particular in patients who have vaginal cuff with distortion posthysterectomy, thus making follow up more challenging. Hoffman et al. reported to have discovered $28 \%$ of occult invasive cancer among 32 patients who underwent upper vaginectomy for VAIN 3 [4]. Indermaur et al. performed upper vaginectomy on 105 patients with VAIN and 12\% were diagnosed with occult invasive cancer (Table 3) [7]. Moreover, occult superficially invasive vaginal carcinoma does not require adjuvant treatment, because previous studies support upper vaginectomy as an appropriate treatment $[13,14]$. Second, it is an effective treatment modality. Diakomanolis et al. reported that in high-grade VAIN, upper vaginectomy has a cure rate of $80 \%$ while laser ablation has a $68 \%$ cure rate. No recurrence was found in the current study, where others have reported recurrence of up to $21 \%$ [11]. Third, it is a safe procedure. A previous study reported that the mean estimated blood loss was $50 \mathrm{ml}$ and the complication rate was $10 \%$. The complications were cystotomy, hemorrhagy at the time of surgery, and wound cellulitis [7]. Our study resulted in 55 (20 to 100) $\mathrm{ml}$ of the mean estimated blood loss and one complication, a vesico-uterine fistula; postoperative bleeding in a patient with warfarin use was reported.

Only four cases are reported here and further studies with larger numbers of patients should be undertaken to confirm the data from this pilot study on laparoscopic vaginectomy. Moreover, long-term follow-up indicated support for laparoscopic vaginectomy as a treatment choice for VAIN and superficially invasive vaginal carcinoma.

\section{Conclusions}

As mentioned previously, this is the first study to report LUV for post-hysterectomy VAIN and superficially invasive vaginal carcinoma by the laparoscopic approach. Laparoscopy has an advantage over the conventional approach in that the clinician can identify the distorted anatomy. The method would bring fewer complications, because the adherence of the bladder and rectum to the vault, resulting from the previous operation, is more easily dissected than in the vaginal approach. Moreover, it is an appropriate modality for patients with vaginal stenosis from prior therapy or postmenopausal vaginal atrophy. Though the study has its limitation in the small number of patients and in surgical and clinical outcomes with relatively short-term follow up, our study suggests the feasibility and efficacy of the laparoscopic vaginectomy for the post-hysterectomy patients with VAIN and superficially invasive vaginal carcinoma.

\section{Consent}

Written informed consent was obtained from the patient for publication of this report and any accompanying images.

\section{Abbreviations}

LUV: Laparoscopic upper vaginectomy; VAIN: Vaginal intraepithelial neoplasia.

\section{Competing interests}

The authors declare that they have no competing interests.

\section{Authors' contributions}

YJC made substantial contributions to conception and design, and acquisition of data. She also drafted the manuscript and revised its final form. SYH and JSP were involved in analysis and interpretation of data. $\mathrm{KHL}$ contributed to interpreting the data and gave final approval of the version to be published. All authors read and approved the final manuscript.

\section{Acknowledgments}

The authors declare that they have no conflicts of interest. No financial support was received for this research.

Received: 10 February 2013 Accepted: 16 May 2013

Published: 3 June 2013

\section{References}

1. Stokes-Lampard H, Wilson S, Waddell C, Ryan A, Holder R, Kehoe S: Vaginal vault smears after hysterectomy for reasons other than malignancy: a systematic review of the literature. BJOG 2006, 113:1354-1365

2. Fleisch MC, Hatch KD: Laparoscopic assisted parametrectomy/upper vaginectomy (LPUV)-technique, applications and results. Gynecol Oncol 2005, 98:420-426.

3. Rome RM, England PG: Management of vaginal intraepithelial neoplasia: a series of 132 cases with long-term follow-up. Int J Gynecol Cancer 2000 10:382-390.

4. Hoffman MS, DeCesare SL, Roberts WS, Fiorica JV, Finan MA, Cavanagh D: Upper vaginectomy for in situ and occult, superficially invasive carcinoma of the vagina. Am J Obstet Gynecol 1992, 166:30-33.

5. Geisler JP, Orr C, Manahan KJ: Robotically-assisted laparoscopic radical parametrectomy and radical vaginectomy. Eur J Gynaecol Oncol 2011, 32:674-676.

6. Mahdavi A, Shamshirsaz AA, Peiretti M, Zakashansky K, Idrees MT, Nezhat F Laparoscopic management of vaginal clear cell adenocarcinoma arising in pelvic endometriosis: Case report and literature review. J Minim Invasive Gynecol 2006, 13:237-241

7. Indermaur MD, Martino MA, Fiorica JV, Roberts WS, Hoffman MS: Upper vaginectomy for the treatment of vaginal intraepithelial neoplasia. Am J Obstet Gynecol 2005, 193:577-580. discussion 580-571.

8. Berek JS, Hacker NF: Berek \& Hacker's gynecologic oncology. 5th edition. Philadelphia: Wolters Kluwer Health/Lippincott Williams \& Wilkins; 2010

9. Aho M, Vesterinen E, Meyer B, Purola E, Paavonen J: Natural history of vaginal intraepithelial neoplasia. Cancer 1991, 68:195-197.

10. Sillman FH, Fruchter RG, Chen YS, Camilien L, Sedlis A, McTigue E: Vaginal intraepithelial neoplasia: risk factors for persistence, recurrence, and invasion and its management. Am J Obstet Gynecol 1997, 176:93-99.

11. Diakomanolis E, Rodolakis A, Boulgaris Z, Blachos G, Michalas S: Treatment of vaginal intraepithelial neoplasia with laser ablation and upper vaginectomy. Gynecol Obstet Invest 2002, 54:17-20.

12. Di Saia PJ, Creasman WT: Clinical gynecologic oncology. 8th edition. Philadelphia, PA: Elsevier/Saunders; 2012 
13. Peters WA 3rd, Kumar NB, Morley GW: Microinvasive carcinoma of the vagina: a distinct clinical entity? Am J Obstet Gynecol 1985, 153:505-507.

14. Eddy GL, Singh KP, Gansler TS: Superficially invasive carcinoma of the vagina following treatment for cervical cancer: a report of six cases. Gynecol Oncol 1990, 36:376-379.

doi:10.1186/1477-7819-11-126

Cite this article as: Choi et al:: Laparoscopic upper vaginectomy for post-hysterectomy high risk vaginal intraepithelial neoplasia and superficially invasive vaginal carcinoma. World Journal of Surgical Oncology 2013 11:126.

\section{Submit your next manuscript to BioMed Central and take full advantage of:}

- Convenient online submission

- Thorough peer review

- No space constraints or color figure charges

- Immediate publication on acceptance

- Inclusion in PubMed, CAS, Scopus and Google Scholar

- Research which is freely available for redistribution 